\title{
Vida Saludable para Personas de Edad: Anote Su Presión Sanguínea ${ }^{1}$
}

\section{Leigh Ann Martin²}

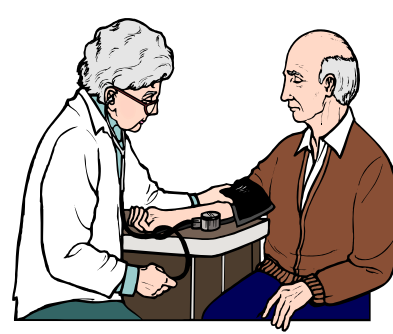

Cada vez que usted se mide la presión sanguínea o se la

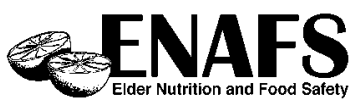

mide un profesional de la salud, anote la fecha y hora, la lectura de la presión, dónde fue medida (en casa, en la clínica del médico, etc.) y cualquier comentario que tenga usted o su profesional de la salud (por ejemplo, algún medicamento que está tomando o ha dejado de tomar, cómo se sentía en esa ocasión o el brazo en el que se hizo la medición).

\begin{tabular}{|l|c|l|l|}
\hline Fecha y Hora & Lectura & Lugar & Comentarios \\
\hline & $/$ & & \\
\hline & 1 & & \\
\hline & 1 & & \\
\hline & 1 & & \\
\hline & 1 & & \\
\hline & 1 & & \\
\hline & 1 & & \\
\hline & 1 & & \\
\hline & 1 & & \\
\hline & 1 & & \\
\hline & 1 & & \\
\hline
\end{tabular}

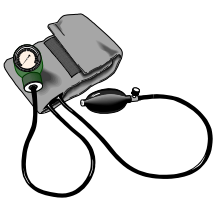

Si tiene preguntas sobre la presión sanguínea o cómo anotarla, háblele a su médico. Para ser referido a una dietista (RD) en su área, llame sin cargo a La Asociación Americana de Dietética al 1-800-366-1655 (disponible en inglés y español).

1. This is document FCS 8601-SPAN, one in a series of the Department of Family, Youth and Community Sciences, Florida Cooperative Extension Service, Institute of Food and Agricultural Sciences, University of Florida, Gainesville, FL 32611. Publication date: March 2004. This leaflet was developed with funding from the Florida Department of Elder Affairs in partnership with state, county, and local agencies. Please visit the EDIS Web site at http://edis.ifas.ufl.edu

2. Leigh Ann Martin, MS, former ENAFS project coordinator, Department of Family, Youth and Community Sciences, Institute of Food and Agricultural Sciences, University of Florida, Gainesville, FL 32611. English version reviewed by Linda B. Bobroff, PhD, RD, LD/N, professor, University of Florida. Translated by Paulina Wittkowsky, MS, RD, former education assistant, University of Florida. Translation reviewed by Isabel Valentín-Oquendo, MS, RD, former FNP curriculum coordinator, University of Florida. 